\title{
Changes and Countermeasures of Ideological and political education in Universities under the background of Internet
}

\author{
Yeqin Lu * \\ College of Technology and Art, Jingdezhen Ceramic Institute, Jingdezhen, 333000, China.
}

\begin{abstract}
Internet has gradually penetrated into all classes of society. As a young group, college students have stronger ability to receive new things, are the main body of the Internet user structure, and are deeply affected by the Internet information. In this case, in order to further improve the effect of Ideological and political education and strengthen the guiding force for the ideological growth of college students, Universities must carry out education layout in the Internet world, build a positive Internet environment for college students, and exert a subtle influence on students' thoughts. At the same time, due to the characteristics of convenient information transmission on the Internet, it can greatly improve the teaching efficiency and quality, make the teaching activities break through the limitation of space and space, and enable students to accept the baptism of Ideological and political education anytime and anywhere.
\end{abstract}

Keywords: Internet; Universities; ideological and political education;

\section{INTRODUCTION}

At the present stage of the development of Internet, its significance in the society is not only a tool for information exchange, but also a perfect virtual world. Multiple ideas collide with each other and various cultures exchange with each other, which has caused a great impact on the thoughts of contemporary college students. While bringing college students a lot of useful knowledge, the Internet, due to its open characteristics, does not refuse bad information. Therefore, for the healthy ideological development of college students, it is necessary to build an internet ideological direction for college students, help students resist the impact of bad information on the Internet, and carry out the ideological and political education reform based on the Internet.

\section{NEW CHANGES OF IDEOLOGICAL AND POLITICAL EDUCATION IN UNIVERSITIES UNDER THE BACKGROUND OF INTERNET}

\subsection{Students are more diversified and pay more attention to personalized expression}

In the new era, due to the open characteristics of the Internet, all kinds of information are welcome, and convenient information transmission channels are provided, which makes the information that college students can access more diversified, Under the influence of multiple information, students' thoughts inevitably develop towards a more diversified direction, and thus spawn a more personalized way of expression. In the process of Ideological and political education, we should not only tell students what is "correct", but also tell students why it is "correct". Only in this way can college students believe in the content of Ideological and political education, and accept and identify with it from the bottom of their hearts ${ }^{[1]}$.

\subsection{The spread of bad information is more convenient, and the damage to college students' spiritual world is more serious}

Before the emergence of the Internet, the transmission of information must rely on the material carrier, which not only seriously limits the speed of information transmission, but also makes the information transmission leave an impression in the material world. However, after the emergence of the Internet, the transmission of information no longer depends on the material carrier, only depends on the data flow on the Internet. Not only does the speed of information transmission break through the limit of spatial distance, it can circulate with the ends of the earth at a very fast speed, and it does not leave a mark in the real world. The staff team cannot carry out effective supervision, but also cannot effectively investigate the responsibility, which makes it difficult to achieve the goal Bad information transmission is more rampant ${ }^{[2]}$.

\subsection{The Internet moral system is gradually rising}

Morality is a common criterion for all members of the society, a high requirement for people's self-cultivation, and does not have the mandatory characteristics of law. As a virtual community, the Internet has gathered a large number of virtual personalities. Based on real life, people express their own voice and ideas in the virtual world. Naturally, they need a set of perfect moral system as institutional support to maintain the health of the Internet environment. College students as the main body of the Internet user structure, their own thoughts, words and deeds, will have a great impact on the establishment of the Internet moral system ${ }^{[3]}$.

\section{Copyright (C) 2020 Yeqin Lu}

doi: 10.18282/1-e.v9i4.1700

This is an open-access article distributed under the terms of the Creative Commons Attribution Non-Commercial License (http://creativecommons.org/licenses/by-nc/4.0/), which permits unrestricted non-commercial use, distribution, and reproduction in any medium, provided the original work is properly cited. 


\section{EFFECTIVE MEASURES OF NETWORK IDEOLOGICAL AND POLITICAL EDUCATION IN UNIVERSITIES UNDER THE BACKGROUND OF INTERNET}

\subsection{Strengthen the construction of network ideological and political education team}

Teachers are the soul of teaching activities. They can give students the most scientific guidance and avoid students' detours to the greatest extent. Especially for ideological and political education, because they are based on the ideological field, they need teachers' earnest guidance. Therefore, the quality of teachers themselves will have a greater impact on the quality of teaching activities, teachers' own teaching ability, have a more profound understanding of Ideological and political education, and can vividly explain the obscure ideological and political education theory ${ }^{[4]}$.

But in real life, due to the influence of the idea of exam oriented education, coupled with the gradual fickleness of people's mind, colleges and students are more concerned about the mastery of knowledge and skills and the improvement of basic ability, and have a certain degree of contempt for ideological and political education, which leads to Universities in the recruitment of Ideological and political education teachers, not to give enough salary, nor to set up a system With strict recruitment conditions, As a result, the team of Ideological and political education teachers is not enough to support the normal development of teaching activities, nor to cope with the great changes of network education. Therefore, Universities must pay more attention to ideological and political education, set up internal teacher "re training" plan, improve teachers' teaching ability, enhance teachers' cognition of Ideological and moral theory, and enhance teachers' comprehensive quality.

\subsection{Pay more attention to the design of network courseware}

For the network teaching work, the most important is the network courseware. Excellent network courseware design, not only requires teachers to have superb teaching ability, can vividly express the content of teaching materials in the network courseware, but also requires teachers to have a certain degree of information ability and information literacy, can support teachers to complete the design of network courseware. However, in real teaching life, college teachers are generally older, have poor ability to accept new things, and lack of information literacy. Although they have rich teaching experience, the limitation of information ability makes them unable to express it in the network courseware. Therefore, Universities must carry out targeted recruitment of information talents, give them higher salary, attract more excellent information talents to apply under the guidance of economic market, so as to solve the limitation of weak information force, and establish a mature promotion mechanism to give them an upward channel. At the same time, the joining of excellent information talents can not only solve the difficulties in the design of network courseware, but also professionally design and maintain the network teaching platform, making the network teaching platform more fluent, thus bringing students a better experience of Ideological and moral education, In addition, it is also helpful to the establishment of campus network firewall, which can enable information talents to design a more efficient firewall mechanism, effectively block the transmission of bad Internet information in the campus, give students a good Internet environment, let students avoid the perplexity of bad temptation in the process of growth, and effectively guarantee the healthy growth of college students ${ }^{[5]}$.

\section{CONCLUSION}

Generally speaking, the Internet is a "double-edged sword", which has both good and bad sides. It can bring convenience to people's work and life, and the hidden bad factors can also cause a certain degree of erosion to people's spiritual world. Especially in today's era of increasing globalization, with the help of the convenient channel of Internet information transmission, "hedonism" and "money worship" in western thoughts continues to invade China's cultural field. College students are the elite talents in the future society, which can play a great role in promoting social development. On the other hand, college students' immature thinking and shallow social experience provide opportunities for western thinking. The fundamental responsibility of Ideological and political education in Universities is to protect the healthy development of College Students' ideology. Under the new situation, we must make a corresponding breakthrough against the Internet and actively open up new areas of network ideological and political education.

\section{Reference}

[1] Wang Hong. The dilemma and Countermeasures of Ideological and political education in Universities under the network environment [J]. Reform and opening up, 2011 (14): 33-34

[2] Cheng Zhaoyu, Guo Tao. Changes and Countermeasures of network ideological and political education in Universities under the background of Internet [J]. Educational theory and practice, 2020,40 (12): 29-31

[3] Zhu Guoping. Research on the current situation, difficulties and Countermeasures of network ideological and political education in Universities [J]. Journal of Three Gorges University (HUMANITIES AND SOCIAL SCIENCES EDITION), 2020,42 (S1): 1-4

[4] Niu Xiaohan, Zhang Bing. Current situation and Countermeasures of network ideological and political education in Universities

[J]. News and communication, 2020 (18): 109-110

[5] Fang Xiaochen. Research on Countermeasures of network ideological and political education in Universities [D]. Anhui Agricultural University, 2013 